be offered-but fortunately they are all that is needed. Especially after a minor head injury the symptom is self limiting, though it may take up to two years to disappear and sometimes never does. When dealing with adolescents the normal child-parent conflicts should be identified and not attributed to the head injury, even though parents might often wish this were the case.

Brain tumours, especially those of the frontal lobe, may lead to personality changes which include irritability. This rarely happens in isolation, however, but is usually associated with other frontal lobe behavioural changes. Temporal lobe abnormalities may also produce various types of aggressive behaviour, but even here irritability is unusual."

We need to remember, then, that irritability is not necessarily abnormal. When it is it is often clearly associated with neuronal damage, usually from a head injury-but it is rarely the sole feature of an intracranial organic lesion. Reassurance, time, and sympathy are the main props of treatment. Even so, many patients will continue with symptoms for some considerable time, possibly indefinitely. Fortunately, irritability is not a debilitating disease.

Consultant Neurosurgeon, Institute of Neurological Sciences, S GALBRAITH Southern General Hospital,

Glasgow G51 4TF

Mover KE. The pswchology of aggression. New York: Harper and Row, 1976 Snaith RP. Taylor CM. Irritability: definition, assessment and associated factors. $\mathrm{Br}$ I Psychicur in press

3 Pitt B. "Atypical" depression following childbirth. Br f Psychiatry 1968;114:1325-35

+ Dalton K. The premenstrual svndrome and progesterone therapv. 2nd ed. London: Heinemann, 1984

McKinla WW Brooks DN, Bond MR Marinage DP. Marshall MM The short term outcome CKinlay WW, Brooks DN, Bond MR, Martinage DP, Marshall MM. The short-term outcome of severe blunt head injury as

6 Brooks DN, McKinlav W. Personality and behavioural change after severe blunt head injury-a relative's view. F Neurol Neurosurg Psvchiatry 1983;46:336-44.

McKinlay W'W', Brooks DN, Bond MR. Post-concussional symptoms, financial compensation McKinlay 'W'W', Brooks DN, Bond MR. Post-concussional symptoms, financial compen
and outcome of severe blunt head injury. F Neurol Neurosurg Psychiatry 1983;46: 1084-91. and outcome of severe blunt head injury. I Neurol Neurosurg Psychiatry 1983;46: 1084-91.
Miller H. Mental sequelae of head injury. Proceedings of the Roval Society of Medicine 1966;59 $257-66$

9 (ironwall D, Wrightson P. Delayed recovery of intellectual function after minor head injury. Lancet 1974; ii: $605-9$

10 Gronwall D, Wrightson P. Cumulative effect of concussion. Lancel 1975:ii:995-7.

11 Devinsky (), Bear D. Varieties of aggressive behavior in temporal lobe epilepsy. Am f Psychuatr 1984:141:651-6.

\title{
Biochemical tests for acute pancreatitis
}

Faced with a battery of biochemical tests and new imaging techniques what laboratory aid should the clinician seek when considering the diagnosis of acute pancreatitis? The value of serum amylase estimations was reported first in 1929 , and it remains the most requested test in this disorder. Measurements of the enzyme by a variety of simple kits are available as a 24 hour service in most laboratories. The activity rises within two to 12 hours of the onset of symptoms and generally returns to normal within three to five days. And yet as a diagnostic test the serum amylase activity has many drawbacks. It is not specific; there are many other causes for hyperamylasaemia. ${ }^{2}$ Raised activities have no prognostic significance. Activities may be normal in $10 \%$ of fatal cases ${ }^{3}$ and when there is associated hypertriglyceridaemia. $^{+}$

More worrying, perhaps, is the failure to agree on what activity is diagnostic of acute pancreatitis. A survey of six commonly consulted textbooks of general medicine and of gastroenterology reflects this imprecision, with statements ranging from a twofold, or threefold, or fourfold rise being significant to a comment that the greater the hyperamylasaemia the more certain is the cause to be acute pancreatitis.

The total serum amylase activity represents a mixture of salivary and pancreatic amylases, the latter accounting for $35-40 \%$ of total activity. Commercial kits are available to measure serum pancreatic isoamylase activities. Although there have been claims that the isoenzyme estimation is clinically helpful, ${ }^{56}$ recent reports suggest that it has little diagnostic advantage as a routine assay for acute pancreatitis. ${ }^{27}$

Urinary amylase activities, the amylase:creatinine clearance ratio, and isoamylase activities have no advantage over serum measurements and pose similar problems in interpretation. ${ }^{28}$

Serum lipase and trypsin(-ogen) activities may also be raised in acute pancreatitis. Lipase estimations have disadvantages compared with amylase and may be raised in nonpancreatic disease. The only source of trypsin in the blood is from the pancreas (a radioimmunoassay for trypsinogen is available $^{y}$ ) and raised activities strongly suggest acute inflammation. ${ }^{10}$

Many other biochemical alterations occur in acute pancreatitis but they are non-specific. Methaemalbuminaemia may accompany other causes of intra-abdominal bleeding than acute necrotising pancreatitis. " $\mathrm{A}$ rise in the blood or serum concentrations of glucose, urea, and lactic dehydrogenase, and a lowering of calcium and albumin concentrations and of the arterial oxygen saturation are individually non-specific but collectively provide a guide to outcome. ${ }^{12}$

Which, then, of the four-amylase, isoamylase, lipase, or trypsin - should be used in routine clinical practice? Using ultrasonography, computed tomography, ${ }^{13-15}$ and laparotomy to establish a diagnosis of acute pancreatitis, Steinberg and his colleagues have assessed the sensitivity and specificity of the four biochemical tests. ${ }^{7}$ All gave good sensitivity but specificity was less satisfactory. More importantly, when they analysed their data using a cut off level that best separated acute pancreatitis from controls with abdominal pain they found that most non-specific rises were of between one- and twofold. Activities in each of the four tests greater than twice normal were almost $100 \%$ specific for acute pancreatitis.

Ultrasonography is widely available. Why should we not use that as the definitive emergency test for acute pancreatitis? Unfortunately, sonograms are normal in one in three patients with mild acute inflammation. Its greatest value is in the diagnosis of pseudocysts,,$^{13+16}$ and in the detection of gall stones in association with acute pancreatitis. ${ }^{17}$ Endoscopic retrograde cholangiopancreatography is contraindicated in acute pancreatitis, and computed tomography is not generally available as an emergency investigation.

Because the serum amylase activity is easy to measure and readily available as a 24 hour service it remains the initial assay of choice. Should it be necessary to show that the hyperamylasaemia is pancreatitic in origin either the isoamylase or trypsinogen activity may be measured; but 
neither is of value in the patient with normal amylase activity and acute pancreatitis. After more than half a century the serum amylase estimation still holds pride of place as the most immediately diagnostic test-and looks set to remain so.

I A D BOUCHIER

Professor of Medicine,

Ninewells Hospital and Medical School,

Dundee DDI 9SY

1 Elman R. Arneson N, Graham E. Value of blond amylase estimation in the diagnosis of pancreatic disease. A clinical studv. Arih Surg 1929;19:942-6;

$2 \mathrm{~K}(x) \mathrm{H}$. Serum levels of pancreatic en $z$ mes and their clinical significance. Clin (jastroenterol 1984:13:739-61

3 Peterson LM, Brooks JR. I.ethal pancreatitis: a diagnestic dilemma. Am 7 Surg 1979:137:491-6.

4 Salt WB II, Schenker S. Amvlase-its clinical significance: a review of the literature. Medhime 1976:55:269-89.
5 Koehler DF, Eckfeldt JH, Levitt MD. Diagnostic value of routine isoamylase assay of hyperamilasemic serum. (iastroenterolog. 1982:82:887-90.

Kolars JC, Ellis CJ, Levitt MD. Comparison of serum amylase pancreatic isoamylase and lipase in patients with hyperamylasemia. Dig Dis S

paticnts with heram pancreatitis. A study of sensitivity and specificity. Am Intern Med 1985;102:576-80.

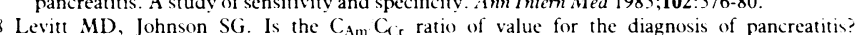
Gustom, Johnson s6. 1s the

Gastroenterolog: 1978,75:118-9.

Malvano R, Marchisio M, Massaglia A, et al. Radioimmunoassay of trypsin-like substance in human serum. Siand f Gastroenterol 1980;15:2-10.

10 Elias $\mathrm{E}$, Redshaw M, W'ord T. Diagnostic importance of changes in circulating concentrations of immunoreactive trypsin. Lancet 1977;ii:66-8

1 Durr GH. Acute pancreatitis. In: Howat HT, Sarles H, cds. The exocrine pancreas. London: W B Saunders, 1979:352-401.

2 Blamey SL, Imrie CW, O'Neill J, Gilmour $W^{\prime} H$, Carter DC. Prognostic factors in acute pancreatitis. Gut 1984:25:1340-6.

3 Meire HB. Ultrasound in gastroenterolngy. Clin (jastroenterol 1984;13:183-203.

4 L.ees W'R. Pancreatic ultrasonography. Clin (jastroenterol 1984:13:763-89.

5 Freenv PC. Computed tomography of the pancreas. Clin (iastroenterol 1984;13:791-818.

16 Silverstein $W$, Isik of $\mathrm{MB}$, Hill MC, Barkin J. Diagnostic imaging of acute pancreatitis: prospective study using CT and sonegraphy. $A 7 R$ 1981;137:497-502.

7 McKay AJ, Imrie CW, O'Neill J, Duncan JG. Is an early ultrasound scan of value in acute pancreatitis? Br 7 Surg 1982:69:369-72.

\section{Hospices: the future}

Press reports of the conference on care of the dying on 2 December concentrated on the opening address by Prince Charles, in which he called for an expansion of the hospice movement. Later speakers at the massive meeting, organised jointly by the National Association of Health Authorities and the Department of Health and Social Security, shared the Prince's conviction that the most important feature of hospice care was the change it had produced in attitudes to death-both in patients and in doctors and nurses. But the health professionals were less expansionist, recognising that the current wave of public enthusiasm for hospice charities was likely to be short lived and that the crucial tasks for the next few years are planning, rationalisation, and education rather than continuing the growth in numbers of hospice buildings.

The health planners' reservations are based on two facts. Firstly, raising the capital sum required to build a hospice from local charitable sources is far easier than finding funds year after year to supply its running costs. Secondly, the current distribution of hospices in Britain is uneven, with the south having far more than the north. Furthermore, new approaches to the care of dying patients-in particular home care (Macmillan) nurses and advisory teams in hospitalshave shown that there are cheaper alternatives to inpatient units and that hospice care is a concept that does not depend on buildings.

The services each health district should have were set out by Professor Eric Wilkes: a specialist advice service on the control of symptoms in patients with terminal cancer, high quality nursing care for those patients, spiritual support for the patient and the family, and a bereavement service. How those skills would be provided would vary with circumstances; in many cases their provision would be shared between the voluntary sector and the National Health Service.

Fortunately, the Minister of Health, Mr Barney Hayhoe, seemed to understand that the way forward lay with a partnership between the NHS and the charities. He "hoped and expected" that health authorities would set up meetings to start the dialogue. Every health district should find out how many patients died each year from cancer and where they died. Next, they should discover what the needs of these patients were and the extent to which they were being met (by inpatient beds, symptom control teams, day centres, home nurses, volunteer services). Finally, each district should draw up a plan for closing the gap between needs and services, taking account of the current and likely future contribution of the voluntary sector.

The reassuring picture left in the audience's mind by the minister's speech was blown away by some realities from a consultant in charge of a continuing care unit, Dr Richard Hillier. Of the 16 such units in the NHS, only one had two consultants. All had fewer nurses than equivalent units in the voluntary sector. If current restraints on spending continued the stark alternative, said Dr Hillier, would be to "tell people to beg or to run a second class nursing home." He went on to call for a training hospice unit in every NHS region linked to a medical school with the funds to support a top quality service and teaching staff.

More than 1000 people attended the meeting-dramatic evidence of the continuing belief among health workers and the public that all dying patients are not yet getting the quality of care given by hospice units. Care of the dying is a specialist skill (though one that at its basic level all doctors should be taught). The cancer charities have achieved wonders in facilitating the spread of this specialist skill-but the final task rests with the DHSS. If and when health districts complete their audits, as requested (but not instructed) by Mr Hayhoe, some money will be needed to help make standards more nearly uniform throughout Britain. No doubt the charities will find a lot of that money-but most of the revenue costs must surely be accepted by the DHSS.

TONY SMITH

Deputy Editor, $B M \mathcal{F}$

\section{Correction}

Probability analysis in the diagnosis of coronary artery disease

We regret that reference 4 was omitted from the leading article "Probability analysis in the diagnosis of coronary artery disease" ( 23 November, $p$ 1443). This should have read: ${ }^{4}$ Diamond GA, Forrester JS. Analysis of probability as an aid to clinical diagnosis of coronary artery disease. $N$ Engl f Med 1979;300:1350-8. 